\title{
Generation Y - Characteristics of Attitudes on Labour Market
}

\author{
Dr. Agnieszka Stanimir
}

\author{
Wroclaw University of Economics, Komandorska 118/120, 53-345 Wroclaw, Poland
} agnieszka.stanimir@ue.wroc.pl

Doi:10.5901/mjss.2015.v6n2s5p22

\section{Abstract}

The purpose of this paper is to present possible attitudes of Gen Y on the labour market, characteristics that can be used in the management of young employees. Second purpose of this paper is to find if the assessment of present job changed during time for Generation Y. Gen Y are persons almost adults but with a less than 35 years, they were born in the 80s and 90s of the twentieth century. This period is conventional and in each country the cohorts may be different. Affiliation to the generation $Y$ depends on the culture, lifestyle, family and friends patterns, social surrounding. Deal $(2007, p$. 14) writes that all generations have similar values and "they just express them differently". In Parment (2013) may be find that identity, image and social networks have become increasingly important in the job seeking process. These same characteristics that also affect the perception of conditions of work and the obligation to work. Gen Y do not want to work as hard as the older generations. They don't believe that work is important part of life, but they tend to work-life balance. Because Gen Y are multitasking, so they willingness to learn new thing is stronger than in older persons. They are also ready to work hard, but only when their work is meaningful. After analysis of the ESS data, it was found that between Poles and the respondents belonging to the countries participating in the ESS there are differences in the perception of the present job, and that the attitude to work of Gen $Y$ in 2004, was changed in 2010. The paper concludes with suggestions for the employers, how to manage Generation Y.

Keywords: Generation Y, labour market, characteristics of the work and employees

\section{Introduction}

The objective of research concerns on detecting differences between four generations on labour market and analysis of changes in attitudes to work. The analysis allowed to determine the guidelines for managers of employees of Gen Y.

This article presents the results of research conducted on the Data ESS Round2 and Data ESS Round5 (ESS European Social Survey). From the questionnaires were taken questions about assessment of current job:

1) Job is secure;

2) Job requires learning new things.

Each respondent chose one of the given response: Not at all true, a little true, quite true, very true. The analysis was conducted for the data from the years 2004 and 2010. In first period, the study group was aged 18-29 years (divided into two groups 18-24 and 25-29). Then were checked the attitudes after six years for these groups, so in 2010 the study group was aged 18-35 years. All persons from the age group 18-30 in 2010 belonged to the Generation $Y$, and respondents 31-35 year old belonged in 2010 to Generation X. Gender of respondents was also taken into consideration in analyses. In 2004 in survey (ESS Round2 and ESS Round5) participated respondents from 26 countries, and in 2010 from 28 countries.

Generation Y (Gen Y, Millennials, Yers) is the best educated group in the current labour market. They are the youngest, but they realize their knowledge and skills, they want to be equally, respectfully treated. Generation $Y$ grew up with free access to modern technologies, therefore, their ability to use ICT in their everyday lives and work are much better than workers from other generations. Generation $Y$ grew up in the age of globalised economy "surrounded by mobile phones and the Internet" (Barwińska-Małajowicz, p. 302) e-mails, e-commities. For them Internet is that place where they may find everything.

Gen $Y$ are born in the 80s and 90s of the twentieth century. Therefore, this group includes people who are already functioning the labour market (age 25-34), those that are starting a job search (18-24) and the youngest Yers who are completing their training (14-17). The youngest group of Yers after entering the labour market will be even more surprising for the other generations, their ability to use modern technology will become more natural.

In the labour market, there are still three other generations: Traditionalists (1922-1945), Baby Boomers (19461964), Generation X (1965-1980). Each of these generations behaves differently in the labour market, but it should be 
noted that the difficulties indicated by one generation are other advantages. Bakowska (2013, p. 10) writes that " Each generation has its own occupational preferences and its own market needs". Can be identified the conventional age cohorts in each country, however, this distribution may be different. Apart from the most frequently mentioned four generations could in fact be several other groups of the population.

Traditionalists (Veterans, Silent Generation, Matures, see for ex. Parry and Urwin (2011)) traditionalists are the oldest people that currently the most frequently are no longer working, but it is still among them a group of professionally active (compare Figure 2). People of this generation are very loyal employees, a fully respect for the authority. They are very involved in their work. They are not open to changes. Thrifty and preferring cash payments, what is related to their risk aversion. They are strongly attached to respect of procedures.

Baby Boomers (BB) are persons who were born after WWII during the demography explosion. Parment (2013) indicates that the baby boom started earlier in the US than in Germany, where the phenomenon was inhibited by the destruction and poverty after WWII. Sometimes this group is divided into two generations: Boomers I (Traditionals, born 1946-1954) and Boomers II (Generation Jones, born 1955-1965) (Schroer, 2015). They differ of their objectives, priorities, scope of use of available technology and dealing with money. However, it can be concluded that all the Baby Boomers have similar attitude to work. They are loyal and say that hard work should be associated with the position, prestige and career advancement. BB move their family away into the background when they have to fulfil their professional duties (Bakowska 2013). Greater financial opportunities and the availability of higher education degrees focused them on career. (Loretto 2015). Baby Boomers are in many cases the parents of Xers and even Yers. It Baby Boomers gave the Xers and Yers access to better living and modern technology.

Generation X is also called "Baby Busters, Twenty something, and the F-you generation" (Acar 2014, p. 12). As Ruthus (2014) explained, people from generation $X$ are individualistic career-oriented, so they are looking for development opportunities in work, they make pragmatic and rational decisions. They appreciate family life. They have a respect for work. Although they are sceptical, they are loyal to their employer. They like to be independent. Because Xers grew up in a period intensified technological developments, their expectations of quality of life are much higher than those of previous generations. "Freedom is more important to them than money and titles" (Ruthus, 2014. p. 7). The result of the study of Gursoy et al. (2008, p. 451), which was carried out by in-depth focus, is the main characteristic of Gen X as: "Respond to instant gratification, Work to live, Identify with the lone ranger, Friends in high places".

Independently of gender, the share of Yers in the World population exceeds the share of generation X, BB and Traditionalists (Figure 1). For the population of Europe in 2010, the percentage of men and women of Gen $Y$ is lower than the other groups that functioning in the labour market. In Poland there are more persons of Gen $Y$ than Xers and Traditionalist.

Fig 1: The percentage rate of people in 5 age groups in the total population of Poland, Europe and World.

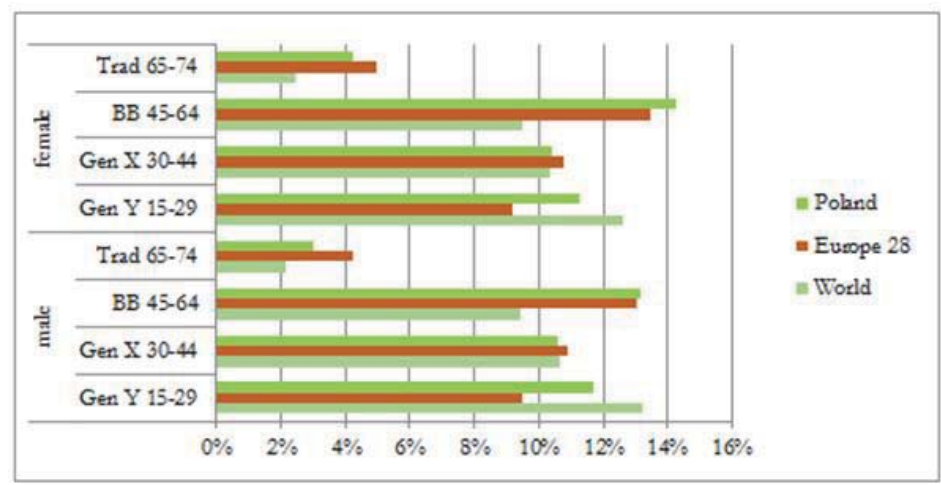

Source: Own elaboration on data from OECD, EUROSTAT [demo_pjangroup].

The next graph (Figure 2) illustrates the employment rate of each generation in 2010. Because EUROSTAT data were used, the age range was adopted identical to those contained in the source table. The employment rate for women from Gen X and younger from BB was in 2010 higher in Poland than the average employment rate in the EU. The employment rate of men from generation $X$ was slightly higher in Poland than in the EU. As shown in Figure 2 the smallest group of those working are people from Traditionalists generation. The employment rate of youngest people from Generation $Y$ is 
much lower than for the other analyzed persons from Yers, Xers and BB. Among people aged 20-24, there are many people who still learning and so the ratio is low (lower for women).

The employment rate (independent of age) for people participating in the labour market is lower for women than for men (both in Poland and in the EU). As seen from Figure 1 the largest part of the population in Poland and Europe are persons of BB generation. Figure 2 shows that the employment rate of people aged $45-49$ years remained at a high level, and for those aged 50-64 is decreasing significantly.

Fig 2: Employment rate in EU and Poland in four generations by gender

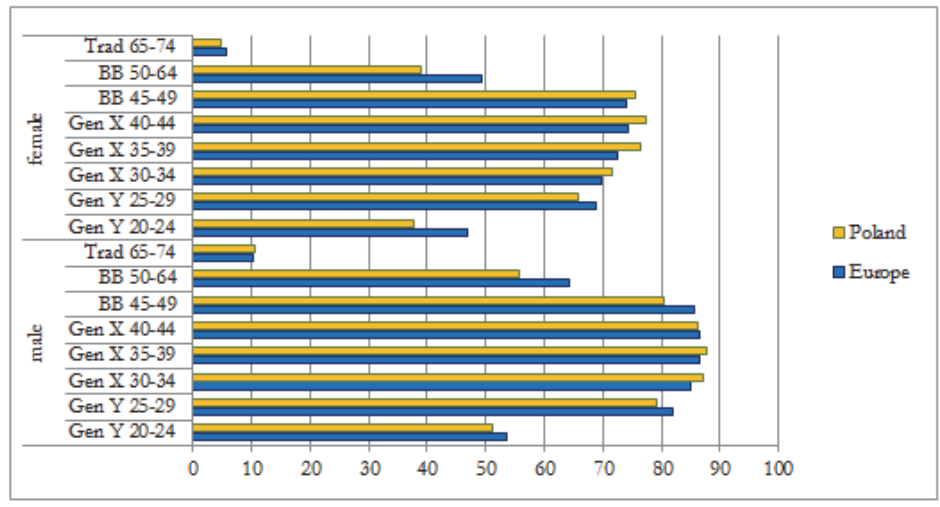

Source: Own elaboration on data from EUROSTAT [lfsa_ergan].

\section{Characteristic of Generation $Y$}

In the literature, can be find another term for Yers: millennium generation, next generation, i-pop generation, e-generation (Barwińska-Mojłowicz 2011). Martini (2005, p. 40) indicates that Gen Y "call themselves the Non-Nuclear Family Generation, the Nothing-Is-Sacred Generation, the Wannabees, the Feel-Good Generation, CyberKids, the Do-or-Die Generation, and the Searching-for-an-Identity Generation". These all names fully reflect the character, lifestyle and attitude to work Generation Y.

Generation Y are people who were born between 1980 and 1999. But those years are conventionally determined. However, in each country, the age cohort may be different. In the Hole, Zhang, Schwartz (2010) can be find examples of generational partitioning occurring in different countries: China, India (Gen Y: 1981+), South Korea (Gen X and Gen Y simultaneously 1970+), Japan, Russia (Gen Y 1983 -2000), South Africa (Gen Y 1990-2000), Brazil (Gen Y 1981-2001), US (Gen Y 1981-2001). Gentry et al. (2011, p. 41) define Gen Y as: "grew up in the digital age".

People belonging to this generation are get used to make permanent many choices (Parment 2013). Thus, multitasking is for them everyday life. Gursoy et al. (2008) suggest that Gen Y expects from their superiors to indicate how to proceed, which results in a lack of ability to make critical decisions.

They have a need for a constant feedback, so that Gen Y can function correctly. In the study described by Parment $(2013$, p. 6) is indicated that $36.4 \%$ of respondents said that "feedback is very important for them and affects their efficiency. " Another characteristic of Gen $Y$ is that the rules are set out in order to be broken (Gursoy et al. 2008). Millennials are a generation without "territorial limitations in communications" (Barwińska-Małajowicz 2011, p. 303). This is due to the fact that from birth they have access to new technologies that they use better than a Generation $X$.

Gen $Y$ freely make decisions whether life or work-related. They are not afraid to open their own business. Martini (2005) indicates that they become the owners of 'Me, Inc. ' (definition in Peters (1997)).

"They know their worth on the labour market" (Barwińska-Małajowicz A. 2011 p. 304). They use the work as an opportunity to achieve other (private) objectives. If they know that by completing the task in a shorter time they will be able to spend the rest of the time on private matters, then they will do the work faster and with greater involvement. It is very difficult determine the dead-line in cooperation with the Gen Y. They are willing to work in teams, and due to their high skills in use of ICT they can work across borders, globally. In such a form of work also helps them tolerance and openness to other lifestyles, cultures and ideologies. Because they like to get the concretized tasks (are task oriented), so they rarely show their creativity in finding solutions. Additionally they are become quickly discouraged when they tend to 
solutions and faced with difficulties. Unlike previous generations, they cannot imagine of work overtime. If they agree to such a solution, they want to be additionally highly paid. Gen $Y$ are very good adapt to the current trend in search of behaviour patterns: "Identitat, Image und soziale Netzwerke spielen eine immer größere Rolle bei der Arbeitssuche" (Parment (2013, p. 58): Identification, image and social networks plays increasingly important role in job searching process). They are the youngest of the labour market, but they are best manage new technologies and social networks.

Gentry et al. (2011) examined what are the differences between three generations of managers due to the importance of factors determining Leadership and their practice and skills in 16 areas. In each generational cohort Importance and skills were different ranked. This points to the fact that the validity of the factors selected by the managers do not goes together with their skills. For example for Y-managers very important were following leadership practices: resourcefulness, leading employees and straightforwardness and composure. But in their skill level these factors were on 6, 15, 7 places, and the most important skills of leadership practices were: being a quick study, differences matter, putting people at ease. In every generational groups leading employees as leadership practices was very important but skill level was very low.

After analyzing the characteristics of all the generations presented on the labour market can be find a lot of differences. Examples of differences are presented in Figure 3.

Fig 3: Differences of work attributes and lifestyle among four generations

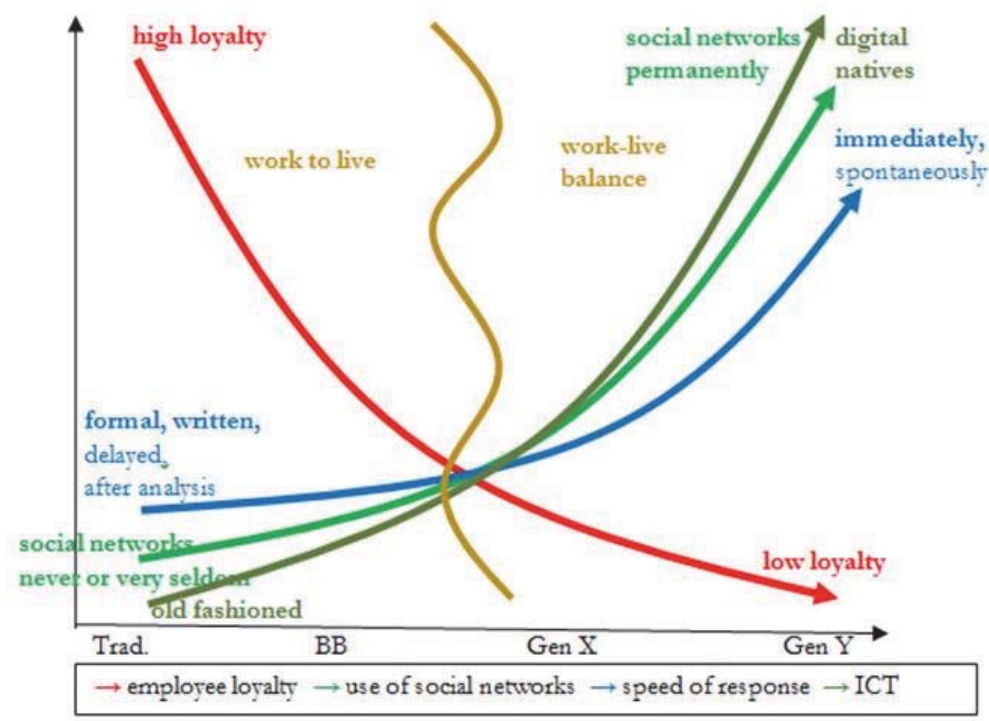

Source: Own elaboration on Bąkowska (2013), Hammill (2005), Parry and Urwin (2011), Twenge (2010), Tolbize (2008).

\section{Analysis of Perceptions of Job Safety and the Possibility of Continuous Learning}

In the Europe 2020 Strategy established in 2010, is indicated fighting poverty and social exclusion as one of headline targets. This action results from the increasing unemployment rate in the European Union. As shown in Stanimir (2014) unemployment rate of Gen Y in the EU decreased in 2006-2008, but from 2009 to 2013 grew. In such a situation, it seems reasonable the question of how youngest employees perceive the stability and job security compared to weaker, than the older generations, loyalty to the employer. 
Fig 4. Job is secure - results of the analysis for the respondents from all countries participating in the ESS

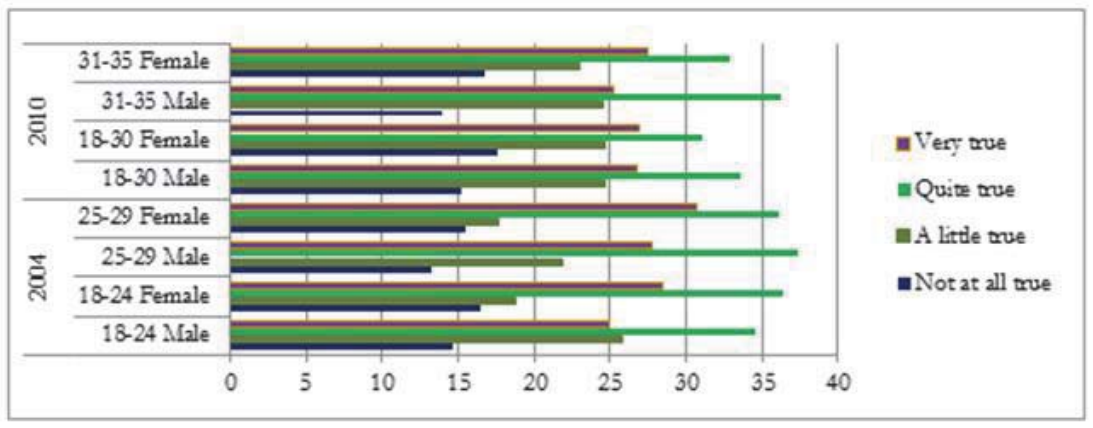

Source: Own elaboration on ESS data.

Fig 5. Job is secure - results of the analysis for the respondents from Poland

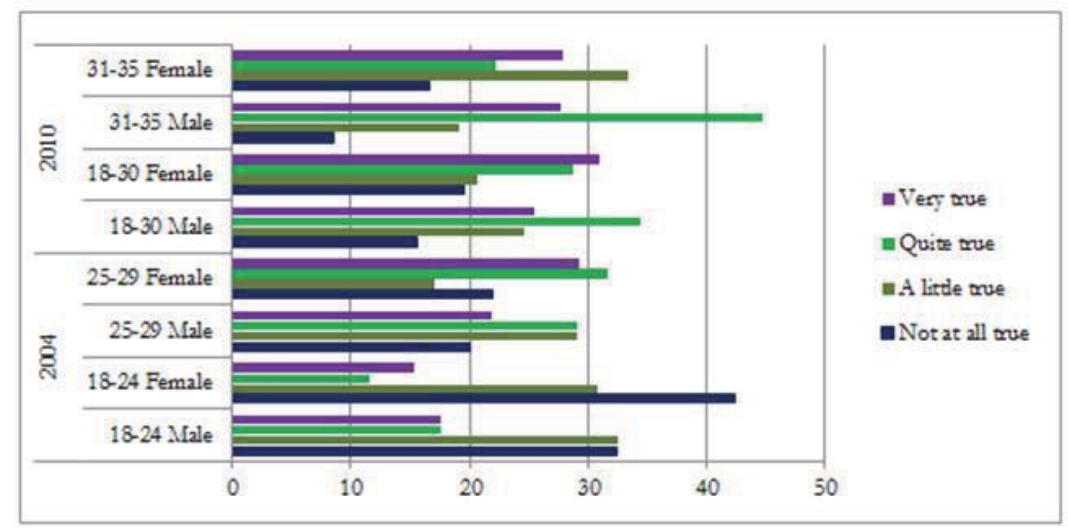

Source: Own elaboration on ESS data.

From figures 4 and 5 it can be seen that in Poland, in both 2004 and 2010 men and women evaluated their job as less secure than all participants of ESS. In Poland in 2004 men and women aged 18-24 assessed the safety of job very unfavourably. After 6 years, they were in the group aged 18-30 years, their assessment of safety has improved, they often chose answers very true and quite true. Analysing the responses of women aged 25-29 in 2004 can be seen that they assess their current job as a highly secure. After six years, their opinions were not so optimistic: the most given answers were a little true. Completely different answered men who in 2004 were 25-29 years: the most common responses were quite true, and a little true. After six years, they better assessed their current work: little true (most replies) and very true. Considering the answers of all respondents in the study of the ESS in 2004 and 2010 there can't be identified changes in the assessment of safety of work. Women aged 25-29 in 2004 and 31-35 in 2010 evaluated their job as the most secure.

Because the Gen $Y$ declares willingness to lifelong learning, it was chosen in the next analysis variables describing their attitude in this matter. Figures 6 and 7 shows how the respondents evaluated the need to learn new things at work. 
Fig 6. Job requires learning new things - results of the analysis for the respondents from all countries participating in the ESS

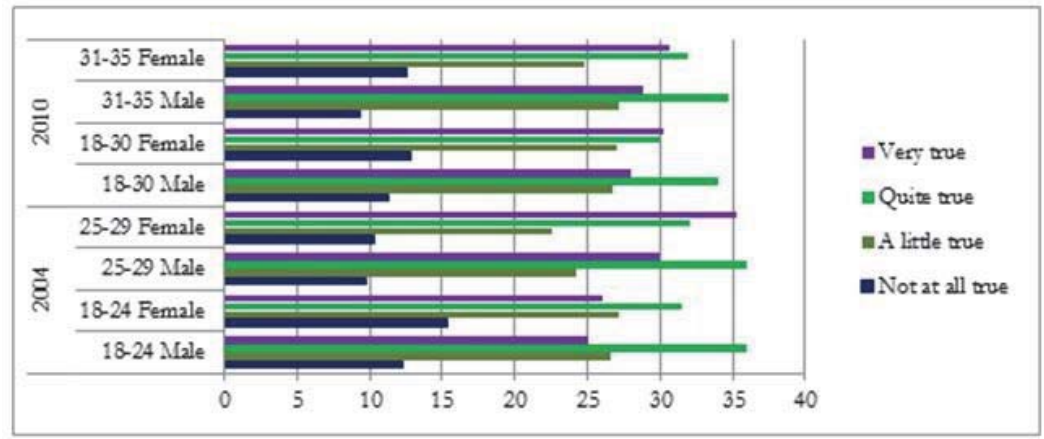

Source: Own elaboration on ESS data.

Fig 7. Job requires learning new things - results of the analysis for the respondents in Poland

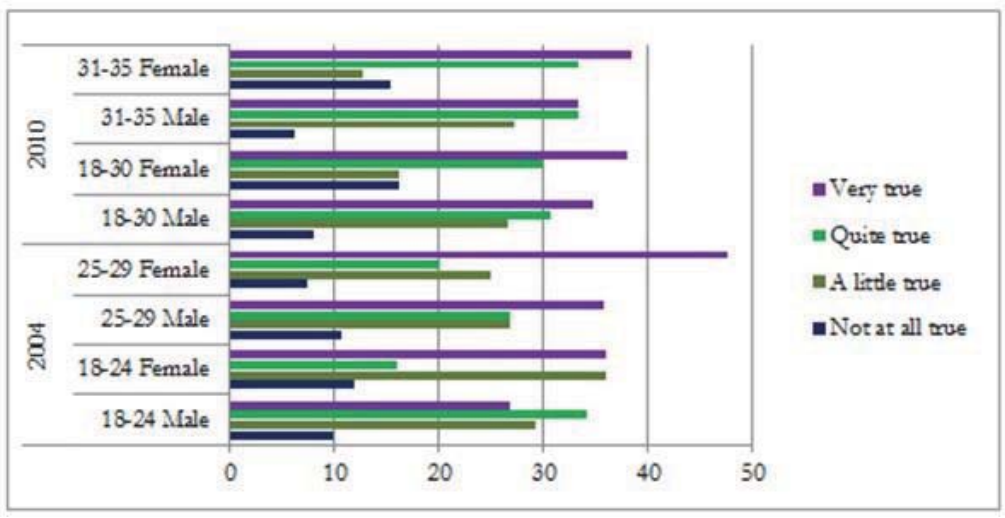

Source: Own elaboration on ESS data.

Statement that the job requires learning new things was true for those of the countries participating in the ESS in both 2004 and 2010 (for men and women). In Poland, in 2004 women aged 25-29 years in most stated that current job requires learning new things. After six years, their opinion was similar. Among women aged 18-24 years in 2004, the most frequent answers were very true and a little true. However, among women aged 18-30 in 2010 were the most answers: very true and quite true.

\section{Conclusions}

Combined analysis based on data from the ESS for all the countries analyzed at the same time does not give a good picture of changes in the perception of work. Each country should be considered separately, and the analysis can be enriched with variables describing the economic situation of the country.

Generation $Y$ declare their willingness to learn new things but probably it must be associated with the possibility of achieving additional benefits not only the execution of work. Unfortunately, the formulation of the questions in ESS does not allow to assess satisfaction with need to learn new things at work.

After the analysis of characteristics of all generations on labour market it is clear that in the management of young employees very important are: possibility of professional development access to modern technology, task oriented management and multitasking, continuous feedback. The employer must allow Gen $Y$ to keep balance between work and life. For Gen Y work is the best place for learning soft and hard skills. 


\section{Acknowledgements}

This study was done as a part of the project "Non-metric multivariate data analysis as a tool for study of adults situation in the context of demographic changes" financed by Narodowe Centrum Nauki (National Science Centre) in Poland. Project number: 2012/05/B/HS4/02499.

\section{References}

Acar A. B. (2014). Do Intrinsic and Extrinsic Motivation Factors Differ for Generation X and Generation Y? International Journal of Business and Social Science, Vol. 5, No. 5, April 2014, p. 12-20.

Barwińska-Małajowicz A. (2011). "Y Generation” on the contemporary labour market - dark fiction or completely new quality? Nierówności społeczne a wzrost gospodarczy, Wydawnictwo Uniwersytetu Rzeszowskiego, zeszyt 19/2011, p. 301-309.

Bakowska J. (2013). Managing Generation Y Employees in an International Company, Working Papers in Management, Finance and Economics, Poznań: MBA Poznań-Atlanta.

Data, ESS Round 2: European Social Survey Round 1. (2004). Data file edition 3. 4. Norwegian Social Science Data Services, Norway Data Archive and distributor of ESS data.

Data, ESS Round 5: European Social Survey Round 6. (2010). Data file edition 3. 2. Norwegian Social Science Data Services, Norway Data Archive and distributor of ESS data.

Deal J. J. (2007). Retiring the Generation Gap: How Employees Young and Old Can Find Common Ground. San Francisco: John Wiley \& Son.

European Commission (2010). Communication from the Commission - Europe 2020. A strategy for smart, sustainable and inclusive growth. European Commission, COM (2010) 2020 final.

Gentry, W. A. , Deal, J. J. , Griggs, T. L. , Mondore, S. P. \& \& Cox, B. D. (2011). A comparison of generational differences in endorsement of leadership practices with actual leadership skill level. Consulting Psychology Journal: Practice \& Research, 63 (1), 39-49.

Gursoy D. , Maier T. A. , Chi C. G. (2008). Generational differences: An examination of work values and generational gaps in the hospitality workforce, International Journal of Hospitality Management 27 (2008), p. 448-458.

Hammill G. (2005), Mixing and Managing Four Generations of Employees, FDUMagazine Online, Winter/Spring 2005, Volume 12, number 2, [Online] Available: http: //www. fdu. edu/newspubs/magazine/05ws/generations. htm (January 31,2015).

Hole D. , Zhang L. , Schwartz J. , (2010). Talking About Whose Generation? Why Western generational models can't account for a global workforce, Deloitte Review Issue 6, p 83-97.

Loretto P. Characteristics of the Baby Boomer, [Online] Available: http: //internships. about. com/od/internships101/qt/Characteristics-OfThe-Baby-Boomer. htm (February 12, 2015).

Martini, C. (2005). From high maintenance to high productivity. What managers need to know about Generation Y, Industrial and Commercial Training, VOL. 37 NO. 1 2005, pp. 39-44.

Parment A. (2013). Die Generation Y Mitarbeiter der Zukunft motivieren, integrieren, führen. Wiesbaden: Springer Fachmedien.

Parry E. , Urwin P. (2011). Generational Differences inWork Values: A Review of Theory and Evidence. International Journal of Management Reviews, Vol. 13, 79-96. DOI: 10. 1111/j. 1468-2370. 2010. 00285. x.

Peters T. (1997). The Brand Called You. Fast Company, August/September 1997, [Online] Available: http://www.fastcompany.com/ magazine/10/august-september-1997 (February 10, 2015).

Ruthus J. (2014). Arbeitgeberattraktivität aus Sicht der Generation Y Handlungsempfehlungen für das Human Resources Management. Wiesbaden: Springer Fachmedien.

Schroer W. (2015). Generations X,Y, Z and the Others - Cont'd. [Online] Available: http: //www. socialmarketing.org/newsletter/features/ generation2. htm (February 10, 2015).

Stanimir A. (2014). Participation in the labour market - Generation $Y$ and other age groups. Academic Journal of Interdisciplinary Studies, MCSER Publishing, Rome-Italy, vol. 3 no. 3. , DOl: 10. 5901/ajis. 2014. v3n3p111.

Tolbize A. (2008). Generational differences in the workplace. Research and Training Center on Community Living, University of Minnesota, [Online] Available: http: //rtc. umn. edu/docs/2_18_Gen_diff_workplace. pdf (February 10, 2015).

Twenge J. M. (2010). A Review of the Empirical Evidence on Generational Differences in Work Attitudes. Journal of Business and Psychology (2010) 25, p. 201-210. 